
\title{
mouse model
}

\author{
Keqiang Chen ${ }^{\# 1}$, Ruoxi Yuan ${ }^{\# 1,2}$, Shuo Geng ${ }^{1}$, Yao Zhang ${ }^{1}$, Taojing Ran ${ }^{1}$, Elizabeth \\ Department of Biological Sciences, Virginia Polytechnic Institute and State University \\ Department of Biomedical Sciences \& Pathobiology, Virginia-Maryland College of Veterinary
}

Abstract \begin{abstract}
eurons is a pathologic hallmark of neurodegenerative diseases. Constitutive autophagy in neurons for maintaining cell survival. also promote neuron death via blockage of autophagy completion. Indeed, we observed significantly higher levels of neuron death in the brain regions of cerebral cortex, hippocampus, (HFD). We further documented diminished density of neurons and increased ratios of TUNEL p62 and Parkin in the brain tissues from $\mathrm{ApoE}^{-/-} / \mathrm{Tollip}^{-/-}$mice as compared to $\mathrm{ApoE}^{-/-}$mice Our data suggest that Tollip may play a crucial tole in sustining neuron healh by facilitating the neurological disease such as Alzheimer's disease.
\end{abstract}

\footnotetext{
**Address correspondence and reprint requests to Prof. Liwu Li, Department of Biological Sciences, Virginia Polytechnic Institute and State University, Life Science 1 Building, Washington Street, Blacksburg, VA 24061. lwli@vt.edu.

Publisher's Disclaimer: This is a PDF file of an unedited manuscript that has been accepted for publication. As a service to our customers we are providing this early version of the manuscript. The manuscript will undergo copyediting, typesetting, and review of the resulting proof before it is published in its final citable form. Please note that during the production process errors may be discovered which could affect the content, and all legal disclaimers that apply to the journal pertain.

Conflict of interest The authors declare that they have no conflicts of interest with the contents of this article.
} 


\section{Keywords}

Tollip; Autophagy; Cell death; Neurodegenerative disease

\section{Introduction}

Neurological disorders such as Alzheimer's disease have significant impacts on human health (Winblad et al., 2016). Among probable causes, the defective clearance of cellular debris and/or aggregated proteins such as $\beta$-amyloid and a-synuclein may exacerbate neurodegeneration (Marsh and Blurton-Jones, 2012; Nilsson et al., 2013; Stefanis, 2012). In neurons, there are two intracellular proteolytic pathways involved in clearing abnormal or obsolete cellular proteins, the ubiquitin-proteasome system (UPS) and the autophagiclysosomal system (Boland et al., 2008). With particular interest, autophagy has been recognized to play a critical role in removing aggregated proteins as well as damaged cellular organelles that are too large for ubiquitin-proteasome system mediated clearance (Rideout et al., 2004). Thus, disruption of autophagy may closely correlate with the pathogenesis of neurodegenerative diseases (Alirezaei et al., 2010).

Autophagy is a complex cellular process that involves the initiation, maturation, and completion (Boland et al., 2008; Klionsky et al., 2008), and the proper degradation of the autophagic substrates is mediated by the fusion of autophagosome with degradative compartments of the endosomal-lysosomal system (Berg et al., 1998). Basal autophagy in neurons assists the clearance of ubiquitinated proteins and damaged organelles such as mitochondria and is critical for maintaining healthy neuron survival (Hara et al., 2006; Komatsu et al., 2006). In contrast, dysfunctional autophagy may lead to neuronal cell death in various disease states such as Alzheimer's disease (Nixon, 2006). Indeed, the accumulation of autophagosomes and other AVs within neurons has been recognized as a pathologic hallmark of many neurodegenerative diseases including Alzheimer's disease (Anglade et al., 1997; Boellaard et al., 1989; Chu, 2006; Kegel et al., 2000; Ko et al., 2005; Nixon et al., 2005; Rubinsztein et al., 2005; Zhu et al., 2007). Despite the emerging clinical significance of defective autophagy completion in neurological disease, molecular mechanisms responsible for proper completion of autophagy are not well understood.

Tollip is a ubiquitously expressed and conserved protein from vertebrate (human, mouse, rat, zebrafish, Xenopus) to worm (TLI-1 in Caenorhabditis elegans), and serves as an adaptor molecule within the Toll-like receptor (TLR) signaling pathway (Bulut et al., 2001). Recent data including studies from our group reveal that Tollip is critically involved in the completion of autophagosome fusion with lysosome in macrophages/monocytes (Baker et al., 2015). Intriguingly, Tollip has also been implicated in the clearance of toxic misfolded protein aggregates in neuronal cells and preventing neuron toxicity (Oguro et al., 2011; Shimizu et al., 2014). Misfolded Protein aggregates accumulate in various neurodegenerative diseases such as polyQ disease (Huntington disease), Alzheimer's disease and Parkinson's disease (Shimizu et al., 2014). Tollip was shown to facilitate the transport of polyQ protein aggregates to late endosome and protect neuronal cells from death (Oguro et al., 2011). Further supporting the role of Tollip in the pathogenesis of human Alzheimer's disease, a 
recent study reported that Tollip expression was significantly reduced in human brain samples collected from aged and Alzheimer's individuals as compared to young individuals (Cribbs et al., 2012). Based on these findings, we aim to examine the causal connection between Tollip deficiency and neurodegeneration in vivo by employing the Tollip deficient mouse model.

ApoE deficient mice offer a unique model to study the pathogenesis of Alzheimer's disease (Avdesh et al., 2011). Under the regimen of high fat diet (HFD) feeding, ApoE deficient mice develop Alzheimer's disease-like symptoms, potentially due to elevated oxidative modifications of proteins, lipids and DNAs resembling AD patients (Galloway et al., 2008; To et al., 2011). A recent study suggest that ApoE deficiency may facilitate the build-up of b-amyloid plaque (Yeh et al., 2016). However, there has been no previous mechanistic study with regard to the regulation of brain cell autophagy due to ApoE deficiency. Intriguingly, HFD has also been shown to potentially reduce the levels of Tollip in muscle tissues (Kim et al., 2010). To further test the role of Tollip in neurodegeneration in a pathologically relevance setting, we have developed the ApoE and Tollip double deficient mice. Utilizing these mice, we aim to examine the role of Tollip during HFD mediated neurodegeneration. We found significantly elevated neuron death in the cerebral cortex, hippocampus, cerebellum and pons in $\mathrm{ApoE}^{-/-} / \mathrm{Tollip}^{-/-}$mice as compared to that in $\mathrm{ApoE}^{-/-}$mice fed with HFD. With particular relevance to Alzheimer's disease, the hippocampus of $\mathrm{ApoE}^{-/-/}$ Tollip $^{-1-}$ mice had significantly less neuron cells. At the molecular level, we observed significant accumulation of autophagosomes in the cytoplasm, elevated levels of p62, Parkin, as well as $\beta$-amyloid and $a$-synuclein aggregation in the neurons of $\mathrm{ApoE}^{-/-} / \mathrm{Tollip}^{-/-}$mice. Our data suggest that Tollip may play a crucial role in modulating neurodegeneration by facilitating the completion of autophagy.

\section{Materials and methods}

\section{Mice}

$\mathrm{ApoE}^{-/-}$mice and $\mathrm{ApoE}^{-/-} / \mathrm{Tollip}^{-/-}$mice were bred and maintained in the animal facility at Virginia Tech with the approved Animal Care and Use Committee protocol. All littermate mice were 8 weeks of age and 25-30 g weight when experiments were initiated.

\section{Experimental design}

$\mathrm{ApoE}^{-/-}$and $\mathrm{ApoE}^{-/-} / \mathrm{Tollip}^{-/-}$mice (male, 8 weeks old) were fed with Western Diet (TD. 88137 , Harlan) for 8 weeks. Western Diet includes cholesterol ( $0.2 \%$ total cholesterol), total fat ( $21 \%$ by weight; $42 \% \mathrm{kcal}$ from fat), saturated fatty acids (> $60 \%$ of total fatty acids), and sucrose ( $34 \%$ by weight).

\section{Histology}

Histological analyses of brain regions including cerebral cortex, Hippocampus, Cerebellum and Pons were performed on freshly frozen, OCT (Optimal-Cutting-Temperature compound)-embedded and sectioned slides $(5 \mu \mathrm{m})$. Slides were fixed in $4 \%$ neutral buffered formalin for $5 \mathrm{~min}$. Haematoxylin and eosin (H\&E) staining were performed. 


\section{Immunofluorescence}

Immunofluorescence analyses were performed on freshly frozen, OCT-embedded and sectioned slides $(10 \mu \mathrm{m}) .6$ mice from $\mathrm{ApoE}^{-/-}$and $\mathrm{ApoE}^{-/-} / \mathrm{Tollip}^{-/-}$mice were used for the study. TUNEL stainings were performed with in situ BrdU-Red DNA Fragmentation (TUNEL) assay Kit according as the product protocol (Abcam). The average numbers of positive staining cells per viewing field were quantified from 2-4 slides collected from each of the six mice.

For the measurement of $\beta$-amyloid, $\alpha$-synuclein, 2-4 Slides from each mouse brain were fixed in $4 \%$ neutrally buffered formalin for $5 \mathrm{~min}$, and stained with anti-mouse primary antibodies (1:100, anti-mouse $\beta$-amyloid, $\boldsymbol{\alpha}$-synuclein antibodies, as well as isotype control antibodies) followed by a biotinylated anti-Ig secondary Ab (BD Biosciences) and streptavidin-PE or FITC. DAPI was used to stain nucleus. 2-4 viewing fields from each slide were captured under fluorescent microscope. Pixel values reflecting the fluorescent intensities of each viewing field were quantitated with the NIH ImageJ software.

\section{Transmission electron microscopy}

Hippocampus area isolated $(2 \mathrm{~mm} \times 2 \mathrm{~mm} \times 1 \mathrm{~mm})$ were fixed in $2.5 \%$ gluteraldehyde in $100 \mathrm{mM}$ sodium cacodylate, $\mathrm{pH} 7.4$, and post-fixed in $1 \%$ osmium tetroxide in sodium cacodylate followed by $1 \%$ uranyl acetate. After ethanol dehydration and embedding in LX112 resin (LADD Research Industries), ultrathin sections were stained with uranyl acetate followed by lead citrate. All grids were viewed on a JEOL 100CX II transmission electron microscope at $80 \mathrm{kV}$. Samples were prepared from the hippocampus regions of 6 $\mathrm{ApoE}^{-/-}$mice and $6 \mathrm{ApoE}^{-/-} / \mathrm{Tollip}^{-/-}$mice fed with HFD for 8 weeks. Two separate hippocampus regions were sampled from each mouse. 5 sections were observed in TEM for each sample. Average numbers of apoptotic cells from three $3 \mathrm{ApoE}^{-/-}$mice and $3 \mathrm{ApoE}^{-/-/}$ Tollip $^{-/}$mice were quantified and presented in Figure 3. Average autophagosome numbers/ cell from observations obtained from 6 mice each were quantified and presented in Figure 3.

\section{Immunoblotting}

Hippocampus blocks ( 100 mg) were harvested, immediately soaked in liquid nitrogen, smashed into power, dissolved in SDS lysis buffer (50 mM Tris-HCl, pH7.0, 2\% SDS, 6\% glycerol, $100 \mathrm{mM}$ DTT) containing a protease inhibitor mixture, and subjected to SDSPAGE. The protein bands were transferred to an Immun-Blot PVDF membrane (Bio-Rad). Western blot analyses were performed as described previously (Baker et al., 2015). Antibodies used for western blot including anti- $\alpha$-synuclein (1:1000) and anti- $\beta$-amyloid (1:1000) were purchased from Abcam. The anti-Parkin (Prk8) (1:1000) and antiSQSTM1/p62 (1:1000) antibodies were purchased from Cell Signaling Technology. The anti- $\beta$-actin (1:2000) antibody was purchased from Santa Cruz Biotechnology.

\section{Statistical analysis}

All experiments were performed at least for 3 times. Representative and reproducible results were shown. Statistical analyses were performed with Prism software (GraphPad Prism 6.0). Values were expressed as means \pm SEM. Student $t$ test was used for parametric analyses between two groups. For non-parametric analyses between two group comparison, the 
significance of the differences was assessed by Mann-Whitney U test. $P<0.05$ was

considered statistically significant.

\section{Results}

\section{Tollip deficiency promotes neuronal cell death}

Utilizing the well-recognized Alzheimer's disease model of ApoE deficient mice (Avdesh et al., 2011; Richardson and Burns, 2002), we examined the effect of Tollip deficiency on neurons and found that the densities of neurons in Cerebral cortex (Fig. 1, upper panel: AB), Hippocampus (Fig. 1, upper panel: C-D), Cerebellum (Fig. 1, upper panel: E-F) and Pon (Fig. 1, upper panel: G-H) were significantly reduced in $\mathrm{ApoE}^{-/-} / \mathrm{Tollip}^{-/-}$mice as compared to $\mathrm{ApoE}^{-/-}$mice. There were many empty spaces of varying sizes in the Cerebral cortex, Hippocampus, Cerebellum of $\mathrm{ApoE}^{-/-} / \mathrm{Tollip}^{-/-}$mice (Fig. 1, upper panel: B, D and F). Missing Purkinje cells could be readily observed in the Cerebellum (Fig. 1, upper panel: E-F). Large necrotic areas could be observed in the Pon region (Fig. 1, upper panel: G-H) of $\mathrm{ApoE}^{-/-} / \mathrm{Tollip}^{-/-}$mice. TUNEL staining revealed significantly increased neuronal cell death in $\mathrm{ApoE}^{-/-} / \mathrm{Tollip}^{-/-}$mice as compared to $\mathrm{ApoE}^{-/-}$mice (Fig. 1, lower panel: A-F, graphs). These results suggest that Tollip deficiency may promote neuronal cell death in vivo.

\section{In hippocampus, neuron death mainly took place in the CA1 region of ApoE-/-/Tollip ${ }^{-/-}$ mice}

In order to further characterize the effect of Tollip on neuronal cell death related to Alzheimer's disease, we focused on the hippocampus region. The hippocampus may be divided into dentate gyrus (DG), CA4, CA3, CA2 and CA1 regions. Interestingly, neuronal cell death mainly occurred in the area of CA1 (Fig. 2A-B) although sporadic dead neurons can be observed throughout the rest of hippocampus. In $\mathrm{ApoE}^{-/-}$mice, the sections of CA1 had a layer of cell bodies of pyramidal neurons with large and prominent nuclei (Fig. 2A-b). In contrast, the pyramidal neurons in CA1 of $\mathrm{ApoE}^{-/-} / \mathrm{Tollip}^{-/-}$mice exhibited necrotic or apoptotic changes characterized by the shrinkage of whole neuron cells with pyknotic nuclei and increased empty spaces around the cells (Fig. 2A-d). The number of TUNEL positive cells in $\mathrm{CA} 1$ area of $\mathrm{ApoE}^{-/-} / \mathrm{Tollip}^{-/-}$mice were significantly higher than that in $\mathrm{ApoE}^{-/-}$ mice as shown in Figure 2B and quantified in the lower panel of Figure 1.

\section{Electron microscopy evaluation of neuronal cell death of CA1 region in ApoE $\mathrm{E}^{-/-} / \mathrm{Tollip}^{-/-}$ mice}

Under transmission electron microscopy (TEM), the amount of neuronal cell death was increased and randomly scattered in CA1 subfield of $\mathrm{ApoE}^{-/-} / \mathrm{Tollip}^{-/-}$mice as compared to $\mathrm{ApoE}^{-/-}$mice (Fig. 3). In ApoE ${ }^{-/}$mice, CA1 pyramidal cells had oval nuclei with evenly dispersed chromatin and clear nucleoli. Cytoplasmic membrane and nucleolemma were intact (Fig. 3 and Fig. 4A-a). The cytoplasm contained mitochondria of various sizes, well developed RER and characteristic polyribosomal rosettes (Fig. 4A-a, b, c). In $\mathrm{ApoE}^{-/-}$ Tollip $^{-/-}$mice, some ultrastructural changes were observed in the CA1 neurons (Fig 3 and Fig. 4B). Some neurons displayed shrinkage and darkening of the whole cell (Fig. 3 and Fig. 4B-a), swelling of the Golgi and RER (Fig. 4B-b, c). In other cells, nucleolemma 
invaginations, chromatin aggregation, cytoplasm lysis (Fig. 4B-d, e, f), and formation of apoptotic bodies were evident (Fig. 4B-g). These results revealed an increase in neuronal

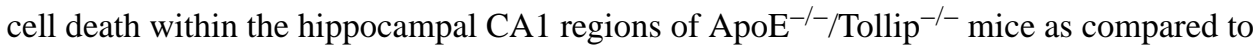
$\mathrm{ApoE}^{-/-}$mice.

\section{Impaired autophagy in neurons of CA1 region from ApoE ${ }^{-/-/ T o l l i p}{ }^{-/-}$mice}

Since autophagy can prevent neuronal cell death (Cheung et al., 2011), we studied whether increased neuronal cell death in $\mathrm{ApoE}^{-/-} / \mathrm{Tollip}^{-/-}$mice may be a result of impaired autophagy completion. TEM analyses revealed that there were more autolysosomes in the cytoplasm of neurons in $\mathrm{ApoE}^{-/-}$mice (Fig.5A-a, c, d). In contrast, more autophagosomes in the neuronal cells of $\mathrm{ApoE}^{-/-} /$Tollip $^{-/}$mice were observed (Fig. 5A-b, c, d). We counted the numbers of cellular autophagosomes on a series of electron micrograph images prepared from $\mathrm{ApoE}^{-/-}$and $\mathrm{ApoE}^{-/-} / \mathrm{Tollip}^{-/-}$neurons and found that the numbers of autophagosomes were significantly greater in $\mathrm{ApoE}^{-/-} / \mathrm{Tollip}^{-/-}$brain cells as compared to $\mathrm{ApoE}^{-/-}$brain cells (Fig. 5B). These results suggest that the autophagy completion at the step of fusion with lysosome may be disrupted in the neurons of $\mathrm{ApoE}^{-/-} / \mathrm{Tollip}^{-/-}$mice brain cells.

In order to confirm that the effect of Tollip on autophagy completion, we investigated the levels of p62/SQSTM1, its accumulation representing the disruption of fused autolysosome formation (Bjorkoy et al., 2009), in the neurons of hippocampus. To achieve this purpose, we harvested the tissues of hippocampus and performed Western Blot analyses. We observed that the levels of p62 were significantly up-regulated in the hippocampus areas of $\mathrm{ApoE}^{-1-/}$ Tollip $^{-1-}$ mice as compared to ApoE ${ }^{-1-}$ mice (Fig. 5C-D). Our data suggest that the autophagy completion may be disrupted in neuronal cells of Tollip deficient mice.

We further investigated the levels of Parkin, a unique, multifunctional ubiquitin ligase associated with p62/SQSTM1 involved in mediating the selective engulfment of depolarized mitochondria by autophagosomes (Narendra et al., 2010) (Gomes and Scorrano, 2013).

Likewise, Parkin was significantly accumulated in the neurons of $\mathrm{ApoE}^{-/-} / \mathrm{Tollip}^{-/-}$mice as compared to $\mathrm{ApoE}^{-/-}$mice (Fig. 5C-E), which further confirmed the disruption of mitophagy completion in neuronal cells from Tollip deficient mice.

\section{Tollip deficiency increased accumulation of $\beta$-amyloid and a-synuclein in neuronal cells}

$\beta$-amyloid peptide aggregates in the neurons can be cleared trhough autophagy. Autophagy deficiency drastically led to aberrant intra-neuronal $\beta$-amyloid accumulation in the perinuclear region of neurons (Nilsson et al., 2013). We observed significantly increased accumulation of $\beta$-amyloid protein in the hippocampus areas including dentate gyrus and CA1 subfield from ApoE ${ }^{-/-} /$Tollip $^{-/}$mice as compared to $\mathrm{ApoE}^{-/-}$mice (Fig. 6A-B). Western blot analyses showed that the levels of $\beta$-amyloid in hippocampus were significantly increased in $\mathrm{ApoE}^{-/-} /$Tollip $^{-/-}$mice as compared to $\mathrm{ApoE}^{-/-}$mice (Fig. 6CD).

In addition to $\beta$-amyloid, $\alpha$-synuclein also tends to accumulate due to the disruption of autophagy (Webb et al., 2003). Furthermore, the accumulation of a-synuclein may serve as a positive feedback in suppressing autophagy (Winslow et al., 2010). Thus, we investigated 
whether Tollip deficiency may contribute to the accumulation of a-synuclein in neuronal cells. We found that the accumulation of a-synuclein in the neurons of hippocampus including dentate gyrus and CA1 subfield was significantly increased in $\mathrm{ApoE}^{-/-} \mathrm{Tollip}^{-/-}$ mice as compared to ApoE ${ }^{-/-}$mice (Fig. 7A-B). Western blot analyses also showed that the levels of a-synuclein in hippocampus were increased significantly in $\mathrm{ApoE}^{-/-} / \mathrm{Tollip}^{-/-}$ mice as compared to $\mathrm{ApoE}^{-/-}$mice (Fig. 7C-D). Taken together, these data further confirmed the disruption of autophagy as well as mitophagy completion in neuronal cells of $\mathrm{ApoE}^{-/-} /$Tollip $^{-/-}$mice.

Complementing our current observation, a previous study reported a reduction of cellular Tollip protein level in mice fed with high fat diet (Kim et al., 2010). The reduction of Tollip may be correlated with an increased risk for Alzheimer's disease. To confirm this observation in our experimental system, we measured Tollip protein levels from brain extracts collected from $\mathrm{ApoE}^{-/-}$mice fed with either regular chow or HFD for two months. Indeed, we observed reduced levels of Tollip protein in brain tissues from $\mathrm{ApoE}^{-/-}$mice fed with high fat diet as compared to $\mathrm{ApoE}^{-/-}$mice fed with regular chow diet (Fig 8).

\section{Discussion}

Our data suggest that Tollip may be involved in the completion of autophagy and mitophagy in neuronal cells in vivo, and that the disruption of Tollip may lead to increased neurodegeneration resembling Alzheimer's disease in mice with ApoE deficient background. Our conclusion is substantiated by the following lines of evidence. First, ApoE and Tollip double deficient mice fed with high fat diet exhibited significantly reduced numbers of neuronal cells within the hippocampus region as compared to ApoE single deficient mice. Second, collective imaging evaluations of hippocampus areas reveal significantly elevated levels of protein aggregates such as $\beta$-amyloid and $\alpha$-syneculein, as well as elevated neuronal cell death in $\mathrm{ApoE}^{-/-} / \mathrm{Tollip}^{-/-}$mice. Third, there were significant accumulations of cellular p62 and Parkin within hippocampus neuronal cells that may serve as molecular indicators of disrupted autophagy and mitophagy.

Our study complements emerging interests in the field of autophagy as it relates to the pathogenesis of neurological diseases including Alzheimer's disease. Most neurodegenerative diseases that afflict humans are associated with the intracytoplasmic deposition of aggregate-prone proteins in neuronal cells. Autophagy is a powerful process for removing such proteins (Frake et al., 2015). The inhibition of constitutive autophagy leads to neurodegeneration in the central nervous system (Hara et al., 2006; Komatsu et al., 2006). Autophagic flux is controlled by the dynamic balance between autophagosome formation and degradation through fusion with lysosome, the impairment of such balance may cause neuronal cell death (Chu, 2006; Zhang et al., 2013). Indeed, the accumulation of autophagosomes in neuronal cells potentially due to the disruption of lysosome fusion has been implicated during the pathogenesis of neurodegenerative diseases such as Alzheimer's disease (Nixon et al., 2005; Yu et al., 2005), Parkinson's disease (Stefanis et al., 2001), and Huntington's disease (Shibata et al., 2006). Alzheimer's disease brain pathology includes intracellular aggregation of $\beta$-amyloid peptide, protein tau and $\beta$-amyloid plaques (Wirths and Bayer, 2012). A role for autophagy in $\beta$-amyloid metabolism has been suggested 
(Boland et al., 2010; Caccamo et al., 2010; Jaeger et al., 2010). Induction of autophagy by rapamycin in vivo reduces intracellular $\beta$-amyloid levels and improves cognition (Caccamo et al., 2011) and long-term rapamycin treatment reduces the plaque load in Alzheimer's disease mice model (Majumder et al., 2011). In contrast, the deletion of autophagy increases both intracellular and extracellular $\beta$-amyloid load (Pickford et al., 2008). Autophagy controls cellular proteostasis by sequestering and delivering protein aggregates and cellular organelles to lysosomes for degradation (Mizushima and Komatsu, 2011). In the Alzheimer's disease brain, autophagosomes accumulate in the neuronal cells indicating impaired autophagy (Nixon, 2007). Recently, it was reported that autophagy deficiency drastically reduced extracellular $\beta$-amyloid plaque burden. This reduction of $\beta$-amyloid plaque load was due to the inhibition of $\beta$-amyloid secretion, which led to aberrant intraneuronal $\beta$ amyloid accumulation in the perinuclear region. In addition to $\beta$-amyloid, other protein aggregates such as polyQ protein and $\alpha$-synuclein have also been shown to accumulate in various forms of neurodegenerative diseases (Komatsu et al., 2007) (Oguro et al., 2011) (Stefanis, 2012). Moreover, autophagy deficiency-induced neurodegeneration was exacerbated by amyloidosis, which together severely impaired brain function (Nilsson et al., 2013).

Despite these significant advancements, definitive studies that demonstrate the causal connection between the disruption of autophagy completion at the level of lysosome fusion with neurodegenerative disease are limited. Tollip was shown to play a key role in the completion of lysosome fusion with endosomes/autophagosomes in the autophagy process. Tollip-deficient macrophages had a constitutive disruption of endosome-lysosome fusion (Baker et al., 2015). In this study, we found that Tollip deficiency led to the accumulation of autophagosomes, up-regulation of p62 and Parkin expression, increased accumulation of $\beta$ Amyloid and a-Synuclein and accelerated neuronal cell death (Fig. 8). Our current data utilizing Tollip deficient mice suggest that the disruption of autophagy completion may indeed serve as an important cause for neuronal cell death, and may support the role of autophagy completion during the pathogenesis of neurodegenerative disease. However, we also realize that the deletion of Tollip may also affect cellular survival and/or death through other mechanisms in addition to autophagy modulation. Future studies are warranted to further examine the causal and complex pathogenesis of Alzheimer's disease due to Tollip deficiency.

The detailed molecular mechanisms responsible for Tollip-mediated fusion of lysosome with autophagosome remain unclear and will need future careful examination. Potential clue may include closely associated adaptor proteins involved in endosomal traffic system such as Tom1 (Target of Myb protein 1) (Katoh et al., 2004; Yamakami et al., 2003). Tollip is localized on endosomes and recruits Tom1 as well as ubiquitinated proteins (Katoh et al., 2004). Tollip was also shown to regulate the function of lipid kinase VPS34, another critical regulator of lysosome fusion with autophagosome (Baker et al., 2015).

Although our current study focused on neuronal cell death, we cannot exclude the contribution of altered neuron regeneration and survival, mediated by neuronal stem cells, neighboring stromal cells as well as immune modulators to neurodegenerative disease (Castorina et al., 2015; Dubovy et al., 2013; Lindvall and Kokaia, 2010). Disrupted 
autophagy and accumulation of autophagosome have been increasingly associated with stem cell proliferation as well as polarization and activation of immune cells (Deretic et al., 2013; Guan et al., 2013). Future studies will be needed to systematically examine the relative contribution of these complex processes to the ultimate outcome of neurodegeneration. Our observation with the $\mathrm{ApoE}^{-/-} / \mathrm{Tollip}^{-/-}$mice will serve as a valuable first step in defining these important questions in future studies. Furthermore, our data suggest that potential intervention strategies aiming at restoring the function of Tollip may hold therapeutic potential in the treatment of neurodegenerative diseases.

\section{Acknowledgements}

The authors thank Kathy Lowe for assistance in transmission electron microscopy. This work is supported by NIH grants R01 HL115835, R56AI108264 to L.L.

\section{Abbreviations}

$\begin{array}{ll}\text { ApoE } & \text { Apolipoprotein E } \\ \text { Tollip } & \text { Toll interacting protein } \\ \text { HFD } & \text { High Fat Diet } \\ \text { TEM } & \text { transmission electron microscopy } \\ \text { AVs } & \text { autophagic vacuoles }\end{array}$

\section{References}

Alirezaei M, Kemball CC, Flynn CT, Wood MR, Whitton JL, Kiosses WB. Short-term fasting induces profound neuronal autophagy. Autophagy. 2010; 6:702-710. [PubMed: 20534972]

Anglade P, Vyas S, Javoy-Agid F, Herrero MT, Michel PP, Marquez J, Mouatt-Prigent A, Ruberg M, Hirsch EC, Agid Y. Apoptosis and autophagy in nigral neurons of patients with Parkinson's disease. Histology and histopathology. 1997; 12:25-31. [PubMed: 9046040]

Avdesh A, Wong P, Martins RN, Martin-Iverson MT. Memory function in a mouse genetic model of Alzheimer's disease. Journal of Alzheimer's disease : JAD. 2011; 25:433-444. [PubMed: 21460433]

Baker B, Geng S, Chen K, Diao N, Yuan R, Xu X, Dougherty S, Stephenson C, Xiong H, Chu HW, Li L. Alteration of Lysosome Fusion and Low-grade Inflammation Mediated by Super-low-dose Endotoxin. J Biol Chem. 2015; 290:6670-6678. [PubMed: 25586187]

Berg TO, Fengsrud M, Stromhaug PE, Berg T, Seglen PO. Isolation and characterization of rat liver amphisomes. Evidence for fusion of autophagosomes with both early and late endosomes. The Journal of biological chemistry. 1998; 273:21883-21892. [PubMed: 9705327]

Bjorkoy G, Lamark T, Pankiv S, Overvatn A, Brech A, Johansen T. Monitoring autophagic degradation of p62/SQSTM1. Methods in enzymology. 2009; 452:181-197. [PubMed: 19200883]

Boellaard JW, Schlote W, Tateishi J. Neuronal autophagy in experimental Creutzfeldt-Jakob's disease. Acta neuropathologica. 1989; 78:410-418. [PubMed: 2675530]

Boland B, Kumar A, Lee S, Platt FM, Wegiel J, Yu WH, Nixon RA. Autophagy induction and autophagosome clearance in neurons: relationship to autophagic pathology in Alzheimer's disease. The Journal of neuroscience : the official journal of the Society for Neuroscience. 2008; 28:69266937. [PubMed: 18596167]

Bulut Y, Faure E, Thomas L, Equils O, Arditi M. Cooperation of Toll-like receptor 2 and 6 for cellular activation by soluble tuberculosis factor and Borrelia burgdorferi outer surface protein A lipoprotein: role of Toll-interacting protein and IL-1 receptor signaling molecules in Toll-like receptor 2 signaling. J Immunol. 2001; 167:987-994. [PubMed: 11441107] 
Castorina A, Szychlinska MA, Marzagalli R, Musumeci G. Mesenchymal stem cells-based therapy as a potential treatment in neurodegenerative disorders: is the escape from senescence an answer? Neural regeneration research. 2015; 10:850-858. [PubMed: 26199588]

Cheung YT, Zhang NQ, Hung CH, Lai CS, Yu MS, So KF, Chang RC. Temporal relationship of autophagy and apoptosis in neurons challenged by low molecular weight beta-amyloid peptide. Journal of cellular and molecular medicine. 2011; 15:244-257. [PubMed: 20015199]

Chu CT. Autophagic stress in neuronal injury and disease. Journal of neuropathology and experimental neurology. 2006; 65:423-432. [PubMed: 16772866]

Cribbs DH, Berchtold NC, Perreau V, Coleman PD, Rogers J, Tenner AJ, Cotman CW. Extensive innate immune gene activation accompanies brain aging, increasing vulnerability to cognitive decline and neurodegeneration: a microarray study. Journal of neuroinflammation. 2012; 9(179):118. [PubMed: 22212381]

Deretic V, Saitoh T, Akira S. Autophagy in infection, inflammation and immunity. Nature reviews. Immunology. 2013; 13:722-737. [PubMed: 24064518]

Dubovy P, Jancalek R, Kubek T. Role of inflammation and cytokines in peripheral nerve regeneration. International review of neurobiology. 2013; 108:173-206. [PubMed: 24083435]

Frake RA, Ricketts T, Menzies FM, Rubinsztein DC. Autophagy and neurodegeneration. The Journal of clinical investigation. 2015; 125:65-74. [PubMed: 25654552]

Galloway S, Pallebage-Gamarallage MM, Takechi R, Jian L, Johnsen RD, Dhaliwal SS, Mamo JC. Synergistic effects of high fat feeding and apolipoprotein E deletion on enterocytic amyloid-beta abundance. Lipids in health and disease. 2008; 7(15):1-8. [PubMed: 18226198]

Gomes LC, Scorrano L. Mitochondrial morphology in mitophagy and macroautophagy. Biochimica et biophysica acta. 2013; 1833:205-212. [PubMed: 22406072]

Guan JL, Simon AK, Prescott M, Menendez JA, Liu F, Wang F, Wang C, Wolvetang E, VazquezMartin A, Zhang J. Autophagy in stem cells. Autophagy. 2013; 9:830-849. [PubMed: 23486312]

Hara T, Nakamura K, Matsui M, Yamamoto A, Nakahara Y, Suzuki-Migishima R, Yokoyama M, Mishima K, Saito I, Okano H, Mizushima N. Suppression of basal autophagy in neural cells causes neurodegenerative disease in mice. Nature. 2006; 441:885-889. [PubMed: 16625204]

Katoh Y, Shiba Y, Mitsuhashi H, Yanagida Y, Takatsu H, Nakayama K. Tollip and Tom1 form a complex and recruit ubiquitin-conjugated proteins onto early endosomes. J Biol Chem. 2004; 279:24435-24443. [PubMed: 15047686]

Kegel KB, Kim M, Sapp E, McIntyre C, Castano JG, Aronin N, DiFiglia M. Huntingtin expression stimulates endosomal-lysosomal activity, endosome tubulation, and autophagy. The Journal of neuroscience : the official journal of the Society for Neuroscience. 2000; 20:7268-7278. [PubMed: 11007884]

Kim SJ, Choi Y, Jun HS, Kim BM, Na HK, Surh YJ, Park T. High-fat diet stimulates IL-1 type I receptor-mediated inflammatory signaling in the skeletal muscle of mice. Mol Nutr Food Res. 2010; 54:1014-1020. [PubMed: 20166142]

Klionsky DJ, Abeliovich H, Agostinis P, Agrawal DK, Aliev G, Askew DS, Baba M, Baehrecke EH, Bahr BA, Ballabio A, Bamber BA, Bassham DC, Bergamini E, Bi X, Biard-Piechaczyk M, Blum JS, Bredesen DE, Brodsky JL, Brumell JH, Brunk UT, Bursch W, Camougrand N, Cebollero E, Cecconi F, Chen Y, Chin LS, Choi A, Chu CT, Chung J, Clarke PG, Clark RS, Clarke SG, Clave C, Cleveland JL, Codogno P, Colombo MI, Coto-Montes A, Cregg JM, Cuervo AM, Debnath J, Demarchi F, Dennis PB, Dennis PA, Deretic V, Devenish RJ, Di Sano F, Dice JF, Difiglia M, Dinesh-Kumar S, Distelhorst CW, Djavaheri-Mergny M, Dorsey FC, Droge W, Dron M, Dunn WA Jr. Duszenko M, Eissa NT, Elazar Z, Esclatine A, Eskelinen EL, Fesus L, Finley KD, Fuentes JM, Fueyo J, Fujisaki K, Galliot B, Gao FB, Gewirtz DA, Gibson SB, Gohla A, Goldberg AL, Gonzalez R, Gonzalez-Estevez C, Gorski S, Gottlieb RA, Haussinger D, He YW, Heidenreich K, Hill JA, Hoyer-Hansen M, Hu X, Huang WP, Iwasaki A, Jaattela M, Jackson WT, Jiang X, Jin S, Johansen T, Jung JU, Kadowaki M, Kang C, Kelekar A, Kessel DH, Kiel JA, Kim HP, Kimchi A, Kinsella TJ, Kiselyov K, Kitamoto K, Knecht E, Komatsu M, Kominami E, Kondo S, Kovacs AL, Kroemer G, Kuan CY, Kumar R, Kundu M, Landry J, Laporte M, Le W, Lei HY, Lenardo MJ, Levine B, Lieberman A, Lim KL, Lin FC, Liou W, Liu LF, Lopez-Berestein G, Lopez-Otin C, Lu B, Macleod KF, Malorni W, Martinet W, Matsuoka K, Mautner J, Meijer AJ, Melendez A, Michels P, Miotto G, Mistiaen WP, Mizushima N, Mograbi B, Monastyrska I, Moore MN, Moreira PI, 
Moriyasu Y, Motyl T, Munz C, Murphy LO, Naqvi NI, Neufeld TP, Nishino I, Nixon RA, Noda T, Nurnberg B, Ogawa M, Oleinick NL, Olsen LJ, Ozpolat B, Paglin S, Palmer GE, Papassideri I, Parkes M, Perlmutter DH, Perry G, Piacentini M, Pinkas-Kramarski R, Prescott M, ProikasCezanne T, Raben N, Rami A, Reggiori F, Rohrer B, Rubinsztein DC, Ryan KM, Sadoshima J, Sakagami H, Sakai Y, Sandri M, Sasakawa C, Sass M, Schneider C, Seglen PO, Seleverstov O, Settleman J, Shacka JJ, Shapiro IM, Sibirny A, Silva-Zacarin EC, Simon HU, Simone C, Simonsen A, Smith MA, Spanel-Borowski K, Srinivas V, Steeves M, Stenmark H, Stromhaug PE, Subauste CS, Sugimoto S, Sulzer D, Suzuki T, Swanson MS, Tabas I, Takeshita F, Talbot NJ, Talloczy Z, Tanaka K, Tanaka K, Tanida I, Taylor GS, Taylor JP, Terman A, Tettamanti G, Thompson CB, Thumm M, Tolkovsky AM, Tooze SA, Truant R, Tumanovska LV, Uchiyama Y, Ueno T, Uzcategui NL, van der Klei I, Vaquero EC, Vellai T, Vogel MW, Wang HG, Webster P, Wiley JW, Xi Z, Xiao G, Yahalom J, Yang JM, Yap G, Yin XM, Yoshimori T, Yu L, Yue Z, Yuzaki M, Zabirnyk O, Zheng X, Zhu X, Deter RL. Guidelines for the use and interpretation of assays for monitoring autophagy in higher eukaryotes. Autophagy. 2008; 4:151-175. [PubMed: 18188003]

Ko DC, Milenkovic L, Beier SM, Manuel H, Buchanan J, Scott MP. Cell-autonomous death of cerebellar purkinje neurons with autophagy in Niemann-Pick type C disease. PLoS genetics. 2005; 1:81-95. [PubMed: 16103921]

Komatsu M, Waguri S, Chiba T, Murata S, Iwata J, Tanida I, Ueno T, Koike M, Uchiyama Y, Kominami E, Tanaka K. Loss of autophagy in the central nervous system causes neurodegeneration in mice. Nature. 2006; 441:880-884. [PubMed: 16625205]

Komatsu M, Waguri S, Koike M, Sou YS, Ueno T, Hara T, Mizushima N, Iwata J, Ezaki J, Murata S, Hamazaki J, Nishito Y, Iemura S, Natsume T, Yanagawa T, Uwayama J, Warabi E, Yoshida H, Ishii T, Kobayashi A, Yamamoto M, Yue Z, Uchiyama Y, Kominami E, Tanaka K. Homeostatic levels of p62 control cytoplasmic inclusion body formation in autophagy-deficient mice. Cell. 2007; 131:1149-1163. [PubMed: 18083104]

Lindvall O, Kokaia Z. Stem cells in human neurodegenerative disorders--time for clinical translation? The Journal of clinical investigation. 2010; 120:29-40. [PubMed: 20051634]

Marsh SE, Blurton-Jones M. Examining the mechanisms that link beta-amyloid and alpha-synuclein pathologies. Alzheimer's research \& therapy. 2012; 4(11):1-8.

Narendra D, Kane LA, Hauser DN, Fearnley IM, Youle RJ. p62/SQSTM1 is required for Parkininduced mitochondrial clustering but not mitophagy; VDAC1 is dispensable for both. Autophagy. 2010; 6:1090-1106. [PubMed: 20890124]

Nilsson P, Loganathan K, Sekiguchi M, Matsuba Y, Hui K, Tsubuki S, Tanaka M, Iwata N, Saito T, Saido TC. Abeta secretion and plaque formation depend on autophagy. Cell reports. 2013; 5:6169. [PubMed: 24095740]

Nixon RA. Autophagy in neurodegenerative disease: friend, foe or turncoat? Trends in neurosciences. 2006; 29:528-535. [PubMed: 16859759]

Nixon RA, Wegiel J, Kumar A, Yu WH, Peterhoff C, Cataldo A, Cuervo AM. Extensive involvement of autophagy in Alzheimer disease: an immuno-electron microscopy study. Journal of neuropathology and experimental neurology. 2005; 64:113-122. [PubMed: 15751225]

Oguro A, Kubota H, Shimizu M, Ishiura S, Atomi Y. Protective role of the ubiquitin binding protein Tollip against the toxicity of polyglutamine-expansion proteins. Neuroscience letters. 2011; 503:234-239. [PubMed: 21896309]

Richardson JA, Burns DK. Mouse models of Alzheimer's disease: a quest for plaques and tangles. ILAR journal / National Research Council, Institute of Laboratory Animal Resources. 2002; 43:89-99.

Rideout HJ, Lang-Rollin I, Stefanis L. Involvement of macroautophagy in the dissolution of neuronal inclusions. The international journal of biochemistry \& cell biology. 2004; 36:2551-2562. [PubMed: 15325592]

Rubinsztein DC, DiFiglia M, Heintz N, Nixon RA, Qin ZH, Ravikumar B, Stefanis L, Tolkovsky A. Autophagy and its possible roles in nervous system diseases, damage and repair. Autophagy. 2005; 1:11-22. [PubMed: 16874045]

Shibata M, Lu T, Furuya T, Degterev A, Mizushima N, Yoshimori T, MacDonald M, Yankner B, Yuan J. Regulation of intracellular accumulation of mutant Huntingtin by Beclin 1. The Journal of biological chemistry. 2006; 281:14474-14485. [PubMed: 16522639] 
Shimizu M, Oguro-Ando A, Ohoto-Fujita E, Atomi Y. Toll-interacting protein pathway: degradation of an ubiquitin-binding protein. Methods in enzymology. 2014; 534:323-330. [PubMed: 24359962]

Stefanis L. alpha-Synuclein in Parkinson's disease. Cold Spring Harbor perspectives in medicine. 2012; 2(a009399):1-24.

Stefanis L, Larsen KE, Rideout HJ, Sulzer D, Greene LA. Expression of A53T mutant but not wildtype alpha-synuclein in PC12 cells induces alterations of the ubiquitin-dependent degradation system, loss of dopamine release, and autophagic cell death. The Journal of neuroscience : the official journal of the Society for Neuroscience. 2001; 21:9549-9560. [PubMed: 11739566]

To AW, Ribe EM, Chuang TT, Schroeder JE, Lovestone S. The epsilon3 and epsilon4 alleles of human APOE differentially affect tau phosphorylation in hyperinsulinemic and pioglitazone treated mice. PloS one. 2011; 6(e16991):1-11.

Webb JL, Ravikumar B, Atkins J, Skepper JN, Rubinsztein DC. Alpha-Synuclein is degraded by both autophagy and the proteasome. The Journal of biological chemistry. 2003; 278:25009-25013. [PubMed: 12719433]

Winblad B, Amouyel P, Andrieu S, Ballard C, Brayne C, Brodaty H, Cedazo-Minguez A, Dubois B, Edvardsson D, Feldman H, Fratiglioni L, Frisoni GB, Gauthier S, Georges J, Graff C, Iqbal K, Jessen F, Johansson G, Jonsson L, Kivipelto M, Knapp M, Mangialasche F, Melis R, Nordberg A, Rikkert MO, Qiu C, Sakmar TP, Scheltens P, Schneider LS, Sperling R, Tjernberg LO, Waldemar G, Wimo A, Zetterberg H. Defeating Alzheimer's disease and other dementias: a priority for European science and society. The Lancet. Neurology. 2016; 15:455-532. [PubMed: 26987701]

Winslow AR, Chen CW, Corrochano S, Acevedo-Arozena A, Gordon DE, Peden AA, Lichtenberg M, Menzies FM, Ravikumar B, Imarisio S, Brown S, O'Kane CJ, Rubinsztein DC. alpha-Synuclein impairs macroautophagy: implications for Parkinson's disease. The Journal of cell biology. 2010; 190:1023-1037. [PubMed: 20855506]

Yamakami M, Yoshimori T, Yokosawa H. Tom1, a VHS domain-containing protein, interacts with tollip, ubiquitin, and clathrin. The Journal of biological chemistry. 2003; 278:52865-52872. [PubMed: 14563850]

Yeh FL, Wang Y, Tom I, Gonzalez LC, Sheng M. TREM2 Binds to Apolipoproteins, Including APOE and CLU/APOJ, and Thereby Facilitates Uptake of Amyloid-Beta by Microglia. Neuron. 2016; 91:328-340. [PubMed: 27477018]

Yu WH, Cuervo AM, Kumar A, Peterhoff CM, Schmidt SD, Lee JH, Mohan PS, Mercken M, Farmery MR, Tjernberg LO, Jiang Y, Duff K, Uchiyama Y, Naslund J, Mathews PM, Cataldo AM, Nixon RA. Macroautophagy--a novel Beta-amyloid peptide-generating pathway activated in Alzheimer's disease. The Journal of cell biology. 2005; 171:87-98. [PubMed: 16203860]

Zhang XJ, Chen S, Huang KX, Le WD. Why should autophagic flux be assessed? Acta pharmacologica Sinica. 2013; 34:595-599. [PubMed: 23474710]

Zhu JH, Horbinski C, Guo F, Watkins S, Uchiyama Y, Chu CT. Regulation of autophagy by extracellular signal-regulated protein kinases during 1-methyl-4-phenylpyridinium-induced cell death. The American journal of pathology. 2007; 170:75-86. [PubMed: 17200184] 


\section{Highlights}

- $\quad$ Tollip deficiency exacerbated neuronal cell death in mouse brain

- $\quad$ Tollip deficiency caused accumulation of $\beta$ amyloid and $a$ - synuclein

- $\quad$ Tollip deficiency may contribute to neuronal accumulation of $\beta$ amyloid and $\alpha$ - synuclein through modulating autophagy as manifested in elevated levels of p62 and Parkin 


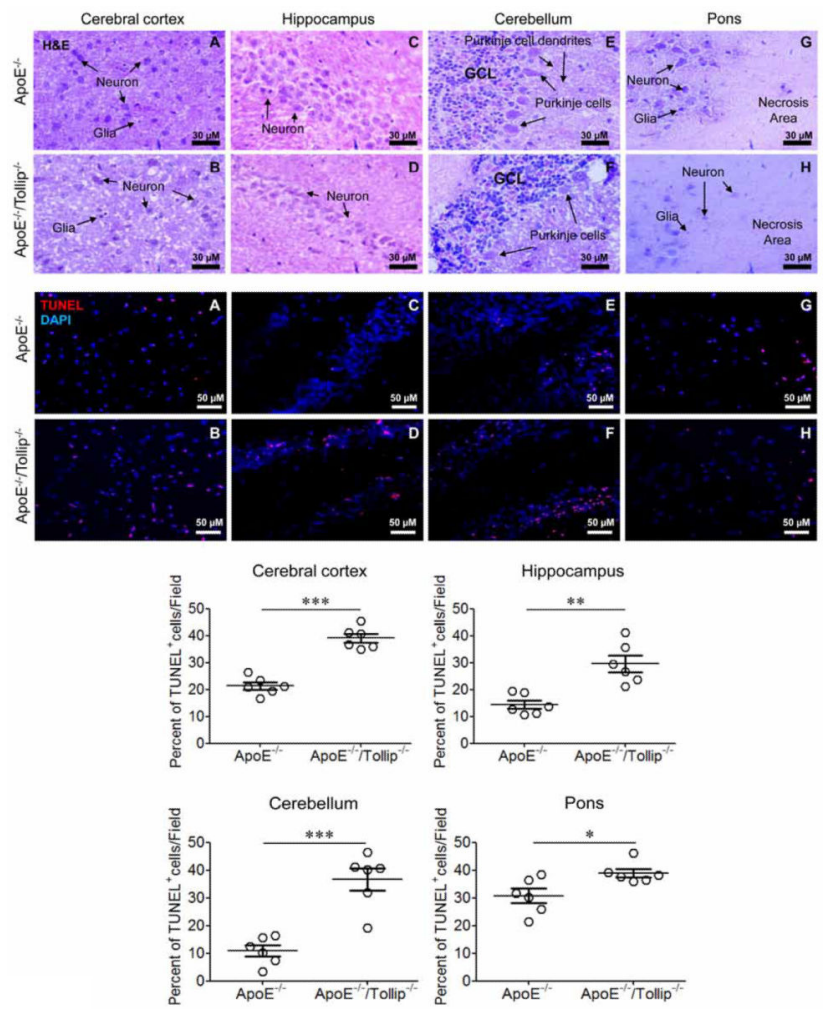

Figure 1. Tollip deficiency caused neurodegeneration in mice The brain tissues of $\mathrm{ApoE}^{-/-}$and $\mathrm{ApoE}^{-/-} /$Tollip $^{-/-}$mice fed with HFD for 2 months were collected and analyzed by $H \& E$ (Upper panel) as well as immuno-histochemical staining (Lower panel). Upper H\&E staining panels: Tollip deficiency reduced the density of neurons in Cerebral cortex, Hippocampus, Cerebellum and Pons. A-B. Cerebral cortex. Scale: $30 \mu \mathrm{m}$. C-D. CA1 subfield in Hippocampus. Scale: $30 \mu \mathrm{m}$. E-F. Cerebellum. GCL: Granule call layer. Scale: $30 \mu \mathrm{m}$. G-H. Pons. Scale: $30 \mu \mathrm{m}$. Lower immune-histochemical staining panels: Tollip deficiency increased neuronal cell death in Cerebral cortex, Hippocampus, Cerebellum and Pons. Red color: TUNEL positive; Blue color: DAPI. A-B. Cerebral cortex. C-D. CA1 subfield in Hippocampus. E-F. Cerebellum. G-H. Pons. Scale: $50 \mu \mathrm{m}$. Percentages of TUNNEL positive cells within various brain regions were quantified and plotted. Error bars represent SEM, N=6 mice brain tissues. * $\mathrm{P}<0.05$; ** $\mathrm{P}<0.01$; *** $\mathrm{P}<0.001$, Mann-Whitney U test. 
A

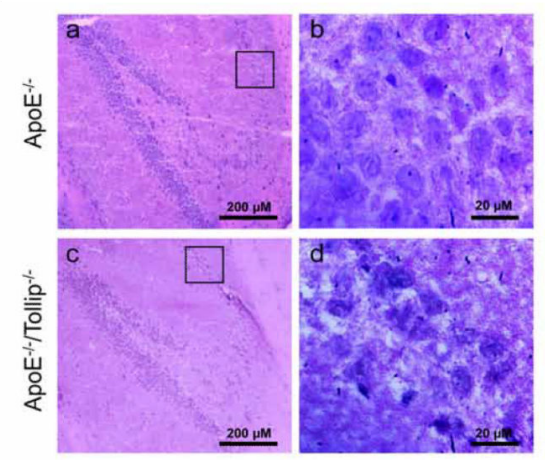

B
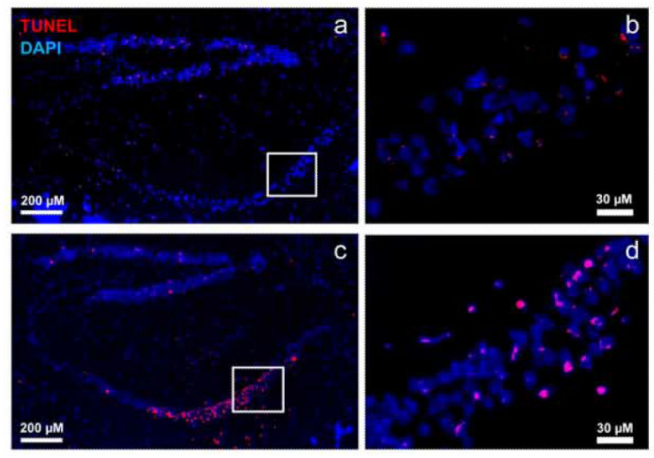

Figure 2. Increased neuron death in CA1 area of hippocampus

The brain tissues of $\mathrm{ApoE}^{-/-}$and $\mathrm{ApoE}^{-/-} /$Tollip $^{-/-}$mice fed with HFD for 2 months were collected and analyzed by $\mathrm{H} \& \mathrm{E}$ as well as immuno-histochemical staining. A. H\&E staining of the CA1 area within the hippocampus. Boxed areas in Aa and Ac were shown in the enlarged images of Ab and Ad respectively. a-c: $200 \mu \mathrm{m}$ and b-d: Scale: $20 \mu \mathrm{m}$. B. TUNEL staining of the hippocampus. Red color: TUNEL positive, blue color: DAPI. Boxed areas in $\mathbf{B a}$ and $\mathbf{B c}$ were shown in the enlarged image of $\mathrm{Bb}$ and $\mathrm{Bd}$ respectively. a-c: 200 $\mu \mathrm{m}$ and b-d: Scale: $30 \mu \mathrm{m}$. 

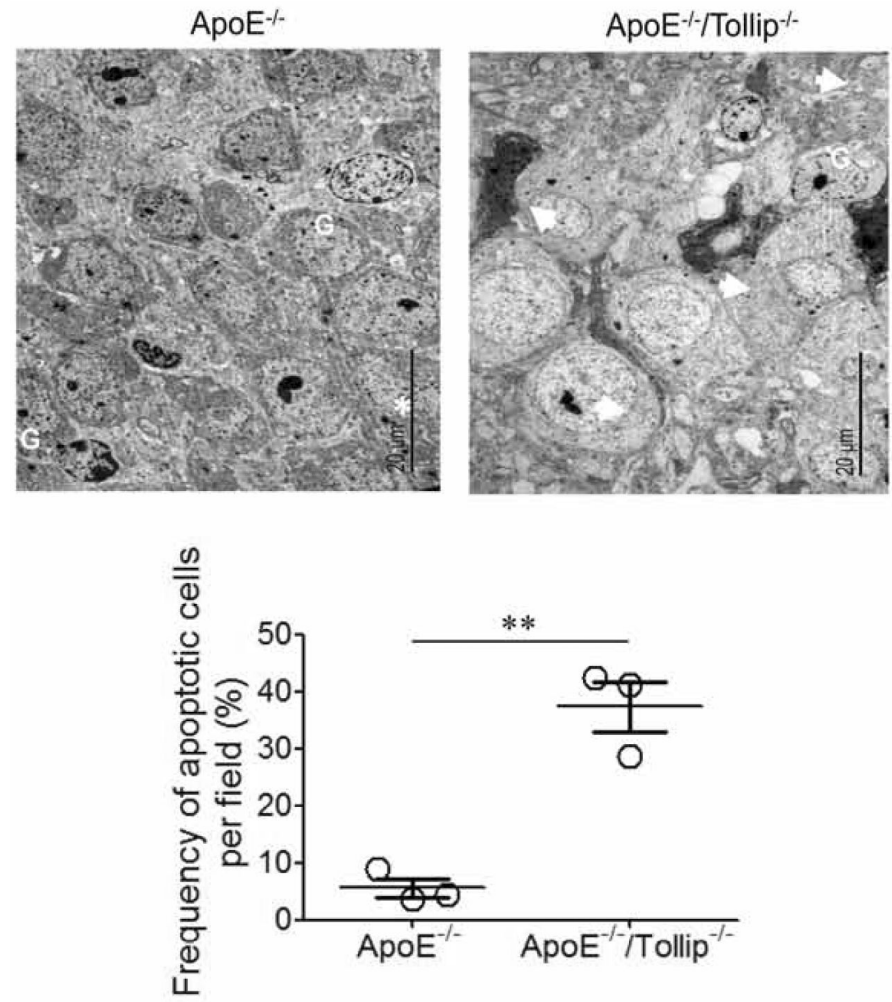

Figure 3. Electron micrograph of a representative neuronal cell in hippocampus of $\mathrm{ApoE}^{-/-}$and ApoE $^{-/-} /$Tollip $^{-l-}$

The brain tissues of $\mathrm{ApoE}^{-/-}$and $\mathrm{ApoE}^{-/-} /$Tollip $^{-/-}$mice fed with HFD for 2 months were processed for TEM analyses. G: Glia; White stars: nucleolus; White arrows: apoptotic cells. Scale: $20 \mu \mathrm{m}$. The percentages of apoptotic cells from the brain tissues of $\mathrm{ApoE}^{-/-}$and ApoE $^{-/-} /$Tollip $^{-/-}$mice were quantified. $\mathrm{N}=3$, ** $\mathrm{P}<0.01$, Mann-Whitney U test. 

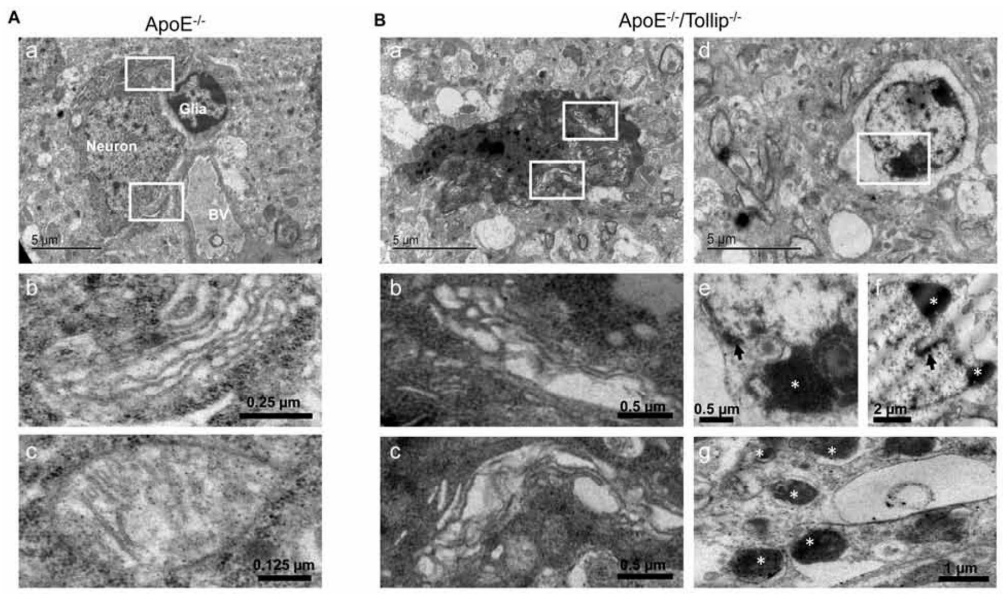

Figure 4. Evaluation of hippocampal neuron death by electron microscopy The brain tissues of $\mathrm{ApoE}^{-/-}$and $\mathrm{ApoE}^{-/-} /$Tollip $^{-/-}$mice fed with HFD for 2 months were collected and analyzed by TEM analyses. A. A representative neuronal cell from CA1 area of hippocampus in ApoE ${ }^{-/-}$mice. A-a. Neuron, glia and blood vessel (BV) were shown. Scale: $5 \mu \mathrm{m}$. A-b and Ac are the magnified versions from the boxed regions shown in A-a. A-b. The magnification of Golgi apparatus, Scale: $0.25 \mu \mathrm{m}$. A-c. The magnification of mitochondria, Scale: $0.125 \mu \mathrm{m}$. B. A representative apoptotic neuron from CA1 area of hippocampus in ApoE ${ }^{-/-} /$TTllip$^{-/-}$mice. B-a. An apoptotic cell. Scale: $5 \mu \mathrm{m}$. B-b and Bc are the magnified versions from the boxed regions shown in B-a. B-b. The magnification of swollen RER, Scale: $0.5 \mu \mathrm{m}$. B-c. The magnification of swollen Golgi apparatus, Scale: 0.5 $\mu \mathrm{m}$. B-d. A dying cell with loss of cytoplasm, nuclear deformity and chromatin aggregation and nuclear membrane invagination. Scale: $5 \mu \mathrm{m}$. B-e-f. The magnification of chromatin aggregation (white star) and nuclear membrane invagination (black arrow), Scale: $0.5 \mu \mathrm{m}$ and $2 \mu \mathrm{m}$. B-g. Showing typical apoptotic bodies (white stars), Scale: $1 \mu \mathrm{m}$. 


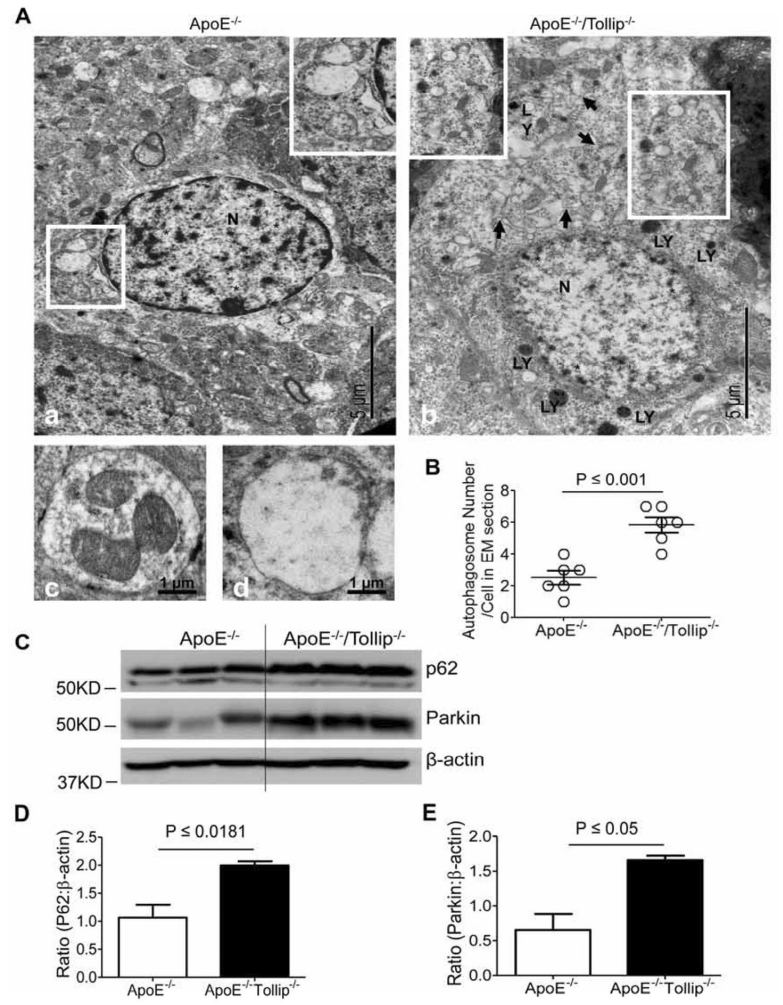

Figure 5. Abnormal autophagy in neurons of CA1 subfield in $\mathrm{ApoE}^{-/-} /$Tollip $^{-/-}$mice The brain tissues of $\mathrm{ApoE}^{-/-}$and $\mathrm{ApoE}^{-/-} / \mathrm{Tollip}^{-/-}$mice fed with HFD for 2 months were collected and analyzed by TEM analyses. A. A representative electron micrograph of neurons. A-a. A typical neuron from $\mathrm{ApoE}^{-/-}$mice, showing autolysosomes. The lower boxed region was enlarged and shown in the upper right corner insert, illustrating the fused

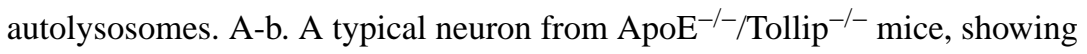
autophagosomes. The lower boxed region was enlarged and shown in the upper left corner insert, illustrating the un-fused autophagosomes. Black arrow: the junction of autophagosome; LY: Lysosomes; N: Nucleus. Insert showing autophagosomes. A-c. A representative early stage autophagosome from $\mathrm{ApoE}^{-/-} / \mathrm{Tollip}^{-1-}$ mice brain. A-d. A representative autolysosome from $\mathrm{ApoE}^{-/-}$mice brain. B. \# of autophagosomes in the $\mathrm{EM}$ sections. $\mathrm{P} \leq 0.001$, Student $\mathrm{t}$ test. $\mathbf{C}$. The tissues of hippocampus from the mice fed with HFD were harvested and the levels of P62, Parkin and $\beta$-actin were determined by Western blotting. D. Ratio (P62: $\beta$-actin), N=3, P $\leq 0.0181$, student $t$ test. E. Ratio (Parkin: $\beta$-actin), $\mathrm{N}=3, \mathrm{P} \leq 0.05$, Mann-Whitney $\mathrm{U}$ test. 
A
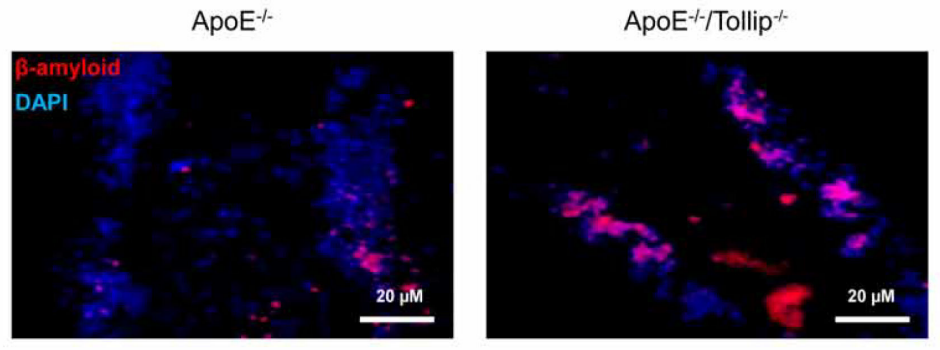

B

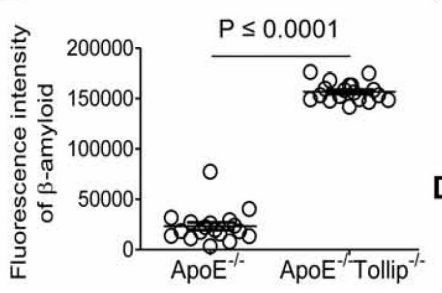

C

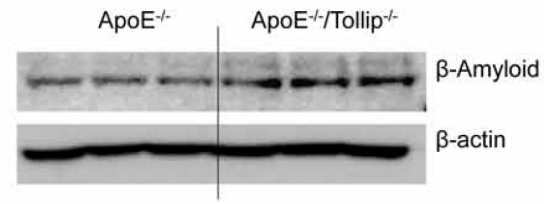

D

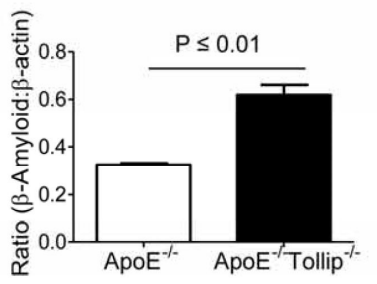

Figure 6. $\boldsymbol{\beta}$-amyloid expression in the neurons of hippocampus

The brain tissues of ApoE $\mathrm{E}^{-/-}$and $\mathrm{ApoE}^{-/-} /$Tollip $^{-/-}$mice fed with HFD for 2 months were collected and analyzed by immuno-histochemical staining as well as Western blot. A. Left: $\beta$-amyloid expression in the neurons of hippocampus from $\mathrm{ApoE}^{-/-}$mice. Right: $\beta$-amyloid expression in the neurons of hippocampus from $\mathrm{ApoE}^{-/-} /$Tollip $^{-/}$mice. Red color: $\beta$ amyloid, Blue color: DAPI. Scale: $20 \mu \mathrm{m}$. B. Fluorescence intensities of $\beta$-amyloid, $N=18$ viewing fields, $\mathrm{P} \leq 0.0001$, Mann-Whitney $\mathrm{U}$ test. $\mathbf{C}$. The levels of $\beta$-amyloid and $\beta$-actin were determined by Western blotting. D. Ratio ( $\beta$-amyloid : $\beta$-actin), $N=3, P \leq 0.01$, student t test. 

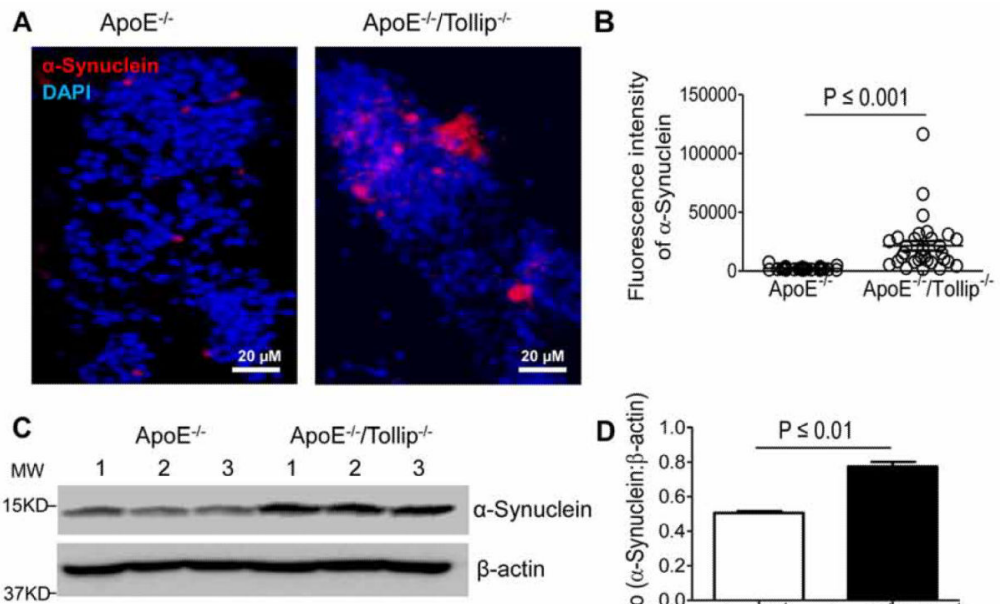

Figure 7. a-synuclein expression in the neurons of hippocampus

The brain tissues of $\mathrm{ApoE}^{-/-}$and $\mathrm{ApoE}^{-/-} /$Tollip $^{-/-}$mice fed with HFD for 2 months were collected and analyzed by immuno-histochemical staining as well as Western blot. A. Left: a-synuclein expression in the neurons of hippocampus from $\mathrm{ApoE}^{-/-}$mice. Right: $\mathbf{a}$ synuclein expression in the neurons of hippocampus from $\mathrm{ApoE}^{-/-} / \mathrm{Tollip}^{-/-}$mice. Red color: a-synuclein, Blue color: DAPI. Scale: $20 \mu \mathrm{m}$. B. Fluorescence intensity of $\beta$-amyloid, $\mathrm{N}=31$ viewing fields, $\mathrm{P} \leq 0.001$, Mann-Whitney $\mathrm{U}$ test. $\mathrm{C}$. The levels of $\mathrm{a}$-Synuclein and $\beta$ actin were determined by Western blotting. D. Ratio ( $a$-synuclein: $\beta$-actin), $N=3, P \leq 0.01$, student $\mathrm{t}$ test. 

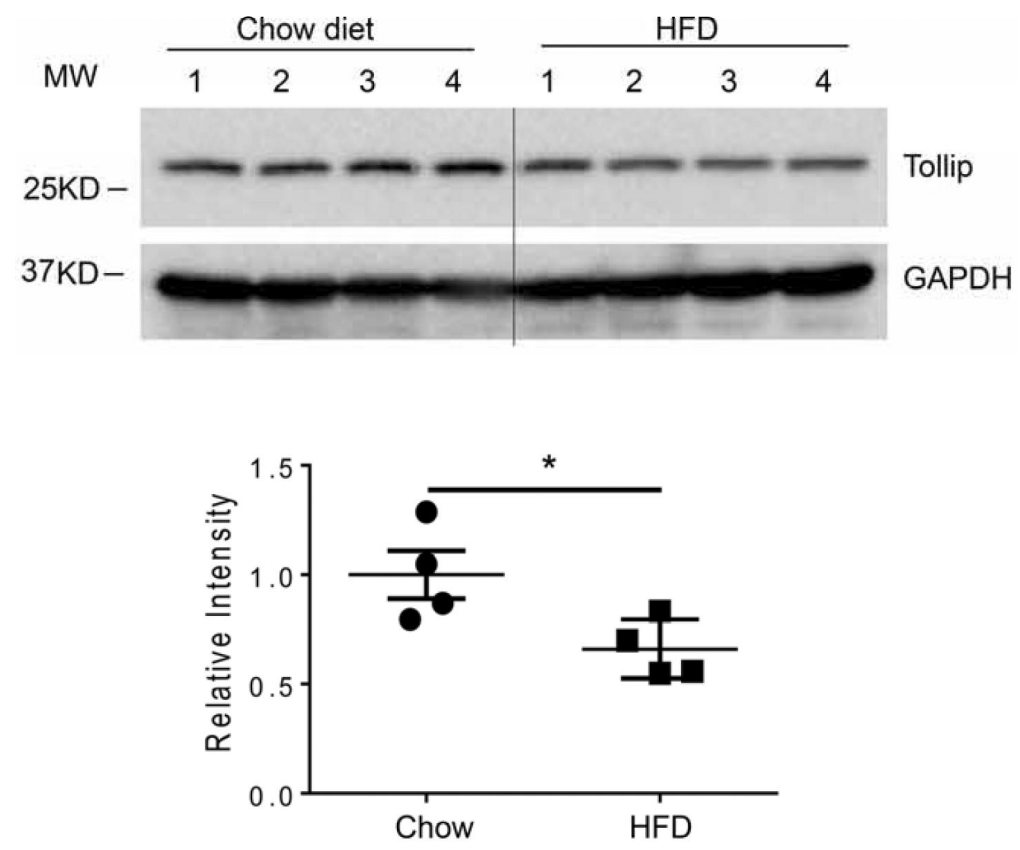

Figure 8. Tollip levels were reduced in brain tissues from $\mathrm{ApoE}^{-/-}$mice fed with high fat diet The brain tissues of $\mathrm{ApoE}^{-/-}$mice fed with regular chow or HFD for 2 months were collected and analyzed by Western blot analyses for the levels of Tollip. $\mathrm{N}=3, \mathrm{P}<0.01$, student $\mathrm{t}$ test. 


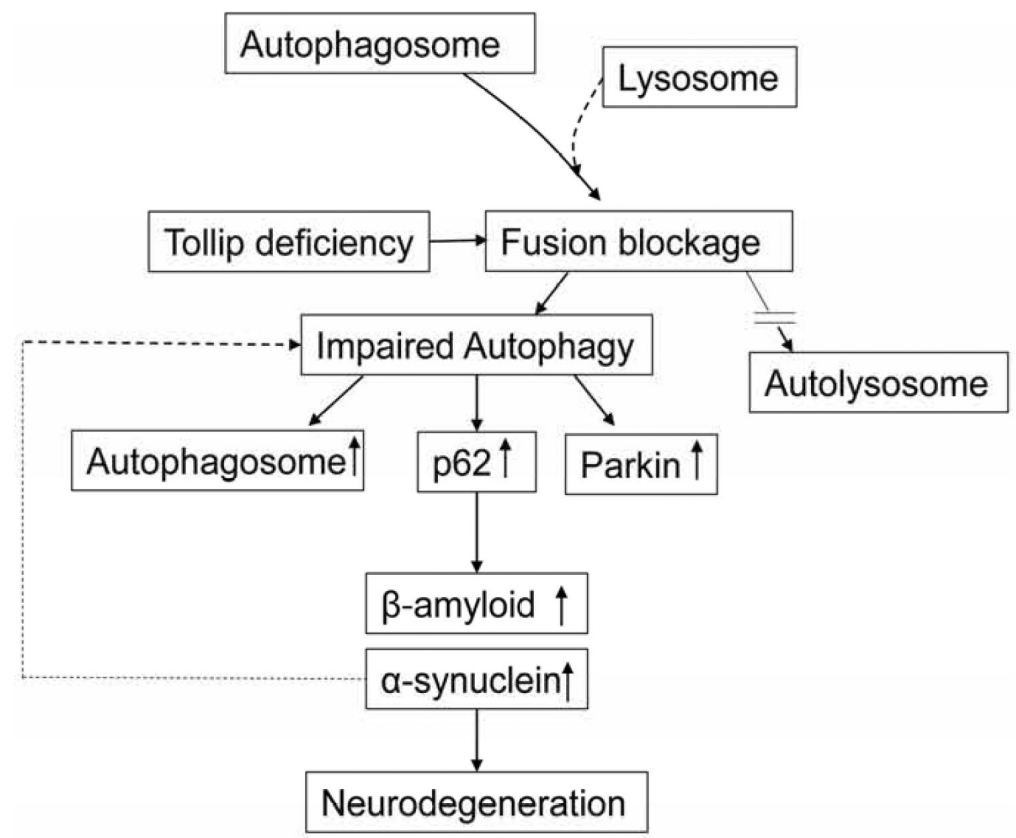

Figure 9.

Tollip deficiency may promote neuronal cell death through impaired fusion of autophagosome with lysosome 